\title{
HUBUNGAN LETAK TEMPAT DUDUK DENGAN PENCAPAIAN NILAI AKHIR BLOK MAHASISWA FAKULTAS KEDOKTERAN UMM ANGKATAN 2008
}

\author{
Lovi Krissadi ${ }^{1}$, Gita Sekar ${ }^{2}$ \\ Rumah Sakit Prima Husada Malang
}

\begin{abstract}
ABSTRAK
HUBUNGAN LETAK TEMPAT DUDUK DENGAN PENCAPAIAN NILAI AKHIR BLOK MAHASISWA FAKULTAS KEDOKTERAN UMM ANGKATAN 2008. Latar Belakang: Hasil kuliah yang maksimal dipengaruhi letak tempat duduk. Mahasiswa yang duduk di depan mendapatkan hasil yang lebih tinggi dibandingkan mahasiswa yang duduk di belakang. Penelitian mengenai letak tempat duduk berpengaruh terhadap hasil akhir mahasiswa dengan membandingkan rata-rata pencapaian nilai akhir mahasiswa yang duduk di barisan depan dan di barisan belakang.

Tujuan: Mengetahui hubungan antara letak tempat duduk dengan pencapaian nilai akhir mahasiswa FK-UMM.

Metode: Retrospektif dengan pendekatan crossectional. Sampel mahasiswa mahasiswa FKUMM semester VII sebanyak 80 mahasiswa yang sedang mengikuti kuliah pakar selama 1 blok. Analisis data menggunakan Kolmogorov - Smirnov, uji Levene, T - student independent.

Hasil: $\quad$ Rata-rata pencapaian nilai akhir mahasiswa yang duduk di tiga baris depan yaitu 66,32, sedangkan mahasiswa yang duduk di tiga baris belakang yaitu 62,3. Pada hasil uji T-student independent didapatkan hubungan yang bermakna antara letak tempat duduk dengan pencapaian nilai akhir blok.

Kesimpulan: Ada hubungan antara letak tempat duduk dengan pencapaian nilai akhir blok.
\end{abstract}

\section{ABSTRACT}

THE CORRELATION BETWEEN SEAT LOCATION AND THE ACHIEVEMENT OF FINAL BLOCK EXAMINATION OF MEDICAL FACULTY 2008 STUDENTS OF MUHAMMADIYAH MALANG UNIVER-

SITY. Background: The achievement of examination is influenced by the seat location. Students who sit in the front row get higher result compared to those are in the back. The research was trying to find out the different between seat location and the achievement of final block examination.

Objective: To find out the correlation between seat location and the achievement of final block examination.

Method: Retrospective with cross sectional approach. The samples were 3rd grade students of Medical Faculty of Mubammadiyah Malang University. This samples was 80 students who were attending lectures for one block. Data analysis was using Kolmogorov-Smirnov, Levene test, T-student independent.

Result: $\quad$ The average achievement of final block of students who sat in the three front row is 66.32, while the students who sat three rows behind the 62.3. At the T-student test results independently obtained a significant association between the location of the seat with the achievement of the final value of the block.

Conclusion: There is a correlation between seat location and the achievement of final block examination of Medical Faculty 2008 Students Of Mubammadiyah Malang University.

Key word : Seat location, the students' final grade achievement

\section{PENDAHULUAN}

Pendidikan di tingkat Perguruan Tinggi merupakan salah satu jenjang pendidikan formal yang mempersiapkan lulusannya untuk bersaing dalam dunia kerja. Melalui pendidikan di Perguruan Tinggi, mahasiswa dididik untuk menjadi seorang yang ahli, profesional dalam suatu ilmu atau bidang keilmuwan, serta sanggup mengabdikannya guna kepentingan masyarakat dan bangsa (Hamalik, 1990).

Tercapainya tujuan pendidikan nasional di atas dapat dilihat dari prestasi belajar yang didapat oleh peserta didik. Menurut pendapat Tirtonegoro (2001) “prestasi belajar adalah hasil dari pengukuran serta penilaian usaha belajar yang dinyatakan dalam bentuk angka, huruf maupun kalimat yang dapat mencerminkan hasil yang sudah dicapai oleh setiap anak dalam periode tertentu." Sedangkan menurut Nana Syaodih Sukmadinata (2003) "prestasi belajar adalah realisasi atau pemekaran dari kecakapan-kecakapan potensial atau kapasitas yang dimiliki seseorang." Dari pengertian ini dapat kita ketahui, bahwa prestasi belajar merupakan tingkat kemanusiaan yang dimiliki siswa dalam menerima, menolak dan menilai informasi-informasi yang diperoleh dalam proses belajar mengajar. 
Prestasi belajar siswa dapat diketahui setelah diadakan evaluasi, yang dinyatakan dalam bentuk nilai. Prestasi belajar siswa dipengaruhi oleh beberapa faktor baik dari dalam diri peserta didik (faktor internal) yang berupa kecerdasan, intelegensi, bakat, minat, kemandirian dan motivasi, maupun faktor dari luar peserta didik (faktor eksternal) berupa lingkungan keluarga, sekolah dan masyarakat.

Dalam situasi mengikuti kuliah di Perguruan Tinggi tercakup aktivitas mendengarkan kuliah dosen, berpikir (mencerna dan memecahkan masalah), berpendapat, berbuat, bertanya, dan berbagai aktivitas fisik dan mental lainnya. Untuk memperoleh hasil kuliah yang maksimal, terdapat beberapa faktor yang hendaknya diperhatikan yaitu: letaknya tempat duduk, berpendapat dan bertanya, menyimpulkan dan menggeneralisasikan (Salam, 2004)

Duduk di depan akan membantu kita untuk lebih masuk ke situasi. Jika duduk di belakang, mahasiswa lebih sering terhalang oleh orang lain dan seringkali tidak dapat mendengar dengan jelas atau lebih mudah terganggu. (Soedarsono, 2006) Atas dasar realita tersebut, maka penulis ingin mengetahui apakah masalah letak tempat duduk berpengaruh terhadap prestasi belajar mahasiswa.

\section{METODE}

Rancangan penelitian yang digunakan adalah retrospektif dengan pendekatan crossectional. Lokasi penelitian bertempat di Fakultas Kedokteran Universitas Muhammadiyah Malang (FK UMM) dan waktu penelitian ini dilakukan selama 1 blok, yaitu Blok Elektif selama 7 minggu.

Populasi dalam penelitian ini adalah mahasiswa FK UMM Angkatan 2008 semester 7 sebanyak 127 mahasiswa. Kemudian disesuaikan dengan kriteria inklusi yaitu mahasiswa FK UMM angkatan 2008 yang sedang mengikuti satu blok, mahasiswa yang duduk di 3 baris depan dan 3 baris belakang dan tidak berpindah minimal $80 \%$ dari kelompok barisan tersebut selama 1 blok perkuliahan dengan absensi kuliah minimal $80 \%$. Kriteria eksklusinya adalah mahasiswa yang duduk berpindah-pindah sebanyak lebih dari $20 \%$ dan mahasiswa yang mengalami gangguan lebih dari 50\% saat perkuliahan, seperti masalah berat dengan keluarga, kuliah atau teman serta masyarakat, atau mengalami sakit yang mengganggu, sehingga didapatkan sampel sebanyak 80 mahasiswa.

Kemudian mahasiswa tersebut diobservasi dengan kuesioner. Selain itu dilakukan pengamatan mengenai kehadiran mahasiswa dan pemilihan tempat duduk mahasiswa saat kuliah berlangsung selama 1 blok. Data sekunder yang juga dibutuhkan adalah nilai akademik mahasiswa FK UMM angkatan 2008. Hasil tersebut diolah dalam bentuk tabel distribusi frekuensi dan tabel silang kemudian data dianalisis dengan T-student independent menggunakan program SPSS.

\section{HASIL DAN PEMBAHASAN}

Penelitian dilakukan terhadap 80 mahasiswa sebagai sampel, diantaranya terbagi menjadi 2 yaitu 45 mahasiswa yang duduk di depan dan 35 mahasiswa yang duduk di belakang Distribusi nilai berdasarkan tempat duduk yang diperoleh tersebut dapat dilihat pada tabel 3 ..

Tabel 1. Hasil Uji Validitas

\begin{tabular}{cccc}
\hline Pertanyaan & Koef & P-value & Keterangan \\
\hline P1 & 0,620 & 0,000 & Valid \\
P2 & 0,369 & 0,001 & Valid \\
P3 & 0,337 & 0,002 & Valid \\
P4 & 0,579 & 0,000 & Valid \\
P5 & 0,619 & 0,000 & Valid \\
P6 & 0,512 & 0,000 & Valid \\
P7 & 0,457 & 0,000 & Valid \\
P8 & 0,280 & 0,009 & Valid \\
P9 & 0,379 & 0,000 & Valid \\
P10 & 0,299 & 0,005 & Valid \\
P11 & 0,309 & 0,004 & Valid \\
P12 & 0,275 & 0,011 & Valid \\
P13 & 0,565 & 0,000 & Valid \\
\hline
\end{tabular}

Tabel 2. Hasil Uji Reliabilitas

\begin{tabular}{cc}
\hline Alpha Cronbach & Hasil \\
\hline 0,632 & Reliabel \\
\hline
\end{tabular}


Tabel 3. Distribusi Nilai Mahasiswa Duduk Depan dan Mahasiswa Duduk Belakang

\begin{tabular}{lcccc}
\hline \multirow{2}{*}{ Rentang Nilai } & \multicolumn{2}{c}{ Mahasiswa Duduk Depan } & \multicolumn{2}{c}{ Mahasiswa Duduk Belakang } \\
\cline { 2 - 5 } & Frekuensi & Persentase & Frekuensi & Persentase \\
\hline$>80$ & 0 & $0 \%$ & 0 & $0 \%$ \\
$75,0-80,0$ & 2 & $4,44 \%$ & 1 & $2,86 \%$ \\
$70,0-74,9$ & 10 & $22,2 \%$ & 5 & $14,29 \%$ \\
$60,0-69,9$ & 29 & $64,4 \%$ & 17 & $48,57 \%$ \\
$55,0-59,9$ & 3 & $6,67 \%$ & 6 & $17,14 \%$ \\
$40,0-54,9$ & 1 & $2,22 \%$ & 6 & $17,14 \%$ \\
$<40$ & 0 & $0 \%$ & 0 & $0 \%$ \\
\hline Jumlah & 45 & $100 \%$ & 35 & $100 \%$ \\
\hline
\end{tabular}

Tabel 4. Statistik Deskriptif

\begin{tabular}{lccccc}
\hline & N & Minimum & Maximum & Mean & Std. Deviation \\
duduk_depan & 45 & 53.75 & 75.50 & 66.3278 & 4.94194 \\
duduk_belakang & 35 & 40.75 & 75.25 & 62.3000 & 8.58496 \\
\hline Valid N (listwise) & 80 & & & & \\
\hline
\end{tabular}

Tabel 5. Hasil Uji T-Student Independen

\begin{tabular}{lccc}
\hline & Nilai t-hitung & $p$-value (sig) & Keputusan \\
$\begin{array}{l}\text { uji } T \text { - student } \\
\text { independent }\end{array}$ & 2,475 & 0,017 & Tolak $\mathrm{H}_{0}$
\end{tabular}

Berdasarkan Tabel 1, untuk uji validitas dapat dijelaskan bahwa setiap pertanyaan mempunyai koefisien korelasi masing-masing variabel nilainya lebih besar daripada 0,3. Selain itu, $p$-value masing-masing variabel nilainya lebih kecil daripada $\alpha=0,05$. Dapat dilihat bahwa semua butir pertanyaan dapat dikatakan valid karena mempunyai nilai signifikansi lebih kecil dari $\alpha(0,05)$, sehingga semua butir dapat diikutsertakan dalam analisis selanjutnya. Dari Tabel 2 didapatkan koefisien Alpha Cronbach untuk semua item pertanyaan lebih besar daripada 0,6. Sehingga dapat disimpulkan bahwa indikator yang digunakan untuk mengukur dapat diandalkan dan reliabel.

Statistik deskriptif berdasarkan nilai minimum, maximum, rata - rata (mean) dan standar deviasi dapat dilihat pada Tabel 4. Berdasarkan tabel tersebut dapat diketahui bahwa mahasiswa yang duduk di depan mendapat nilai lebih tinggi dibandingkan mahasiswa yang duduk di belakang.

Dari Tabel 5 menunjukkan bahwa hipotesis yang digunakan pada penelitian ini adalah hipotesis satu arah, sehingga besarnya nilai $p$ - value dibagi dua guna pengambilan keputusan, berdasarkan hasil yang ada maka besarnya $p-$ value adalah $0,017 / 2=0,0085$, yang mana lebih kecil dari alpha $(0,0085<0,05)$ dan nilai statistik uji $T$ lebih besar dari t tabel nya $(2,475>1,99)$ sehingga $\mathrm{H}_{0}$ di tolak, sehingga dapat disimpulkan bahwa mahasiswa FK UMM 2008 yang duduk di depan mendapatkan nilai akhir blok yang lebih tinggi daripada mahasiswa yang duduk di belakang, atau dengan kata lain bahwa letak tempat duduk mahasiswa bisa mempengaruhi nilai akhir mahasiswa.

Dari Tabel 3 dapat dilihat bahwa mahasiswa yang duduk di depan mendapat nilai yang lebih tinggi daripada mahasiswa yang duduk di belakang. Rentang nilai 60,0-69,9 lebih banyak diraih mahasiswa yang duduk di depan $(64,4 \%)$.
Rentang nilai tertinggi $(75,0-80,0)$ lebih banyak diraih mahasiswa yang duduk di depan (4,44\%). Rentang nilai terendah (40-54,9) lebih banyak diraih mahasiswa yang duduk di belakang $(17,14 \%)$.

Hal ini sesuai dengan riset yang telah dilakukan oleh Purwantoko selama lebih dari 3 tahun terhadap posisi tempat duduk siswa dalam hubungannya pada tingkat keberhasilan belajar siswa di sebuah sekolah, disimpulkan bahwa peringkat lima besar untuk setiap kelas diraih oleh siswa yang menempati posisi tempat duduk maksimal baris tengah hingga baris depan. Sedangkan siswa yang mengambil posisi tempat duduk di bagian belakang rata-rata mendapat peringkat menengah ke bawah. Hasil riset kemudian dilakukan pengujian silang. Yakni salah seorang siswa yang semula mendapat peringkat bagus di kelasnya, menginjak kelas berikutnya dipindah ke tempat duduk bagian belakang. Ternyata prestasinya menurun (Purwantoko, 2010).

Pernyataan Soedarsono (2006) dan Djamarah (2002) juga mendukung penelitian bahwa mahasiswa yang duduk di depan cenderung mendapat nilai yang lebih bagus, dikarenakan faktor-faktor yang mengganggu proses belajar lebih sedikit daripada yang diterima mahasiswa yang duduk di belakang. Sebaliknya, mahasiswa yang duduk di belakang sulit untuk dapat mendengarkan serta melihat apa yang dijelaskan oleh dosen, apalagi jika suara dosen yang terlalu kecil dan ruangan kelas yang besar dengan jumlah mahasiswa yang banyak.

Penelitian ini hanya menganalisis tentang nilai, membandingkan nilai mahasiswa yang duduk di depan dengan nilai mahasiswa yang duduk di belakang tanpa memperhatikan faktor perancu yang mempengaruhi antara lain bakat, minat, IQ, motivasi, sedang mengalami masalah berat serta kenyamanan fasilitas kampus. 


\section{SIMPULAN}

Simpulan yang didapatkan adalah terdapat hubungan yang signifikan (bermakna) antara letak tempat duduk dengan pencapaian nilai akhir mahasiswa FK-UMM 2008 dimana mahasiswa yang duduk di depan mendapat nilai lebih tinggi daripada mahasiswa yang duduk belakang. Rata-rata pencapaian nilai akhir mahasiswa FKUMM 2008 yang duduk di 3 baris depan yaitu 66,3278, sedangkan ratarata nilai yang diperoleh mahasiswa yang duduk di 3 baris belakang yaitu 62,3 .

\section{DAFTAR PUSTAKA}

Abrams, R, 2008, Winning Presentation In A Day. Yogyakarta : Kanisius.

Albertus, Doni Koesoema, 2007, Pendidikan Karakter, Strategi Mendidik, Anak di Zaman Global. Jakarta : Grasindo.

Creswell, J, 2002, Research Design. Jakarta : KIK Press.

Dimyati \& Mudjiono, 2006, Teori Belajar dan Pembelajaran. Jakarta: Depdikbud berkerjasama dengan Rineka

Djamarah, SB, 2000, Guru dan Anak Didik dalam Interaksi Edukatif. Jakarta : .PT. Rineka Cipta.

Djamarah, SB, 2002, Psikologi Belajar. Jakarta : PT. Rineka Cipta.

Diiwandono, SEW, 2002, Psikologi Pendidikan. Jakarta : Grasindo.

Gulo, W, 2002, Metodologi Penelitian, Jakarta : Grasindo.

Hadi, S, 1989, Metodologi Research Jilid III, PT. Andi Offset, Yogyakarta

Hadi, S, 1989, Metodologi Research Jilid IV, PT. Andi Offset, Yogyakarta

Hakim, T, 2002, Mengatasi Gangguan Konsentrasi. Jakarta : Puspaswara.

Hakim, T, 2004, Belajar Secara Efektif. Jakarta : Puspaswara. Harsanto, R, 2007, Pengelolaan Kelas Yang Dinamis. Yogyakarta : Kanisius.

Ismail, Rizabuana, 2009, Metode Penelitian Kualitatif : Dasardasar Pemikiran Melakaukan Penelitian Sosial. Medan : USU Press. 